\title{
THE EFFECT OF DIFFERENT DOSES OF GAMMA IRRADIATION ON THE ECHIS COLORATUS VENOM TOXICITY IN MICE
}

\author{
By \\ ANDREW R. GABRA ${ }^{1}$, MOHAMED MAGED ${ }^{1}$, LAMIAA S. EL-DIN SHAKER ${ }^{2}$, \\ OSAMA A. ABBAS ${ }^{3}$ and SAMAH G. MOHAMED ${ }^{2}$
}

Faculty of Biotechnology, October University for Modern science and Arts, $6{ }^{\text {th }}$ October, Giza' ${ }^{1}$, VACSERA, Applied Research Department, Pilot plant unit, Agouza, Giza ${ }^{2}$, Egypt and Department of Radioisotopes, Egyptian Atomic Energy Authority ${ }^{3}$ ('Correspondence:lamiaa_salah@yahoo.com)

\begin{abstract}
Snake venoms are complex mixtures of proteins and non proteins components. This study evaluated the toxicity effect of $\mathrm{LD}_{50}$ of native Echis coloratus venom and the $\mathrm{LD}_{50}$ of dry venom irradiated with different doses of gamma radiation (2, $5 \& 10 \mathrm{KGy})$ on Swiss albino mice. Measurement of some biochemical parameters and histological alterations in liver and kidney was investigated. The biochemical parameters showed highly significant increase $(\mathrm{P}<0.001)$ in levels of ALT, AST, urea and CK in all groups compared to control group. Levels of serum creatinine showed highly significant increase $(\mathrm{P}<0.001)$ in groups treated with $\mathrm{LD}_{50}$ of crude venom and 5 times $\mathrm{LD}_{50}$ of irradiated venom at 2 and $10 \mathrm{KGy}$, But, showed significant $(\mathrm{P}<0.05)$ with groups treated with 5 times $\mathrm{LD}_{50}$ of irradiated venom at $5 \mathrm{KGy} \& \mathrm{LD}_{50}$ of irradiated venom at $10 \mathrm{KGy}$ showed non-significant in group treated with $\mathrm{LD}_{50}$ of $5 \mathrm{KGy} \& 2 \mathrm{KGy}$ compared to control group. Histological examination showed alterations in liver, kidney in mice injected with crude venom compared to control group. Also, the group of mice which injected with different doses of irradiated venom showed no histopathological alteration in liver and kidney tissues, except the mice group injected with 5 times $\mathrm{LD}_{50}$ of irradiated venom at $2 \mathrm{KGy}$ and the group which injected with 5 times $\mathrm{LD}_{50}$ of irradiated venom at $10 \mathrm{KGy}$ which showed alterations in liver and kidney tissues.
\end{abstract}

Key words: Echis coloratus, $\mathrm{LD}_{50}$, Ionizing radiation, Biochemical examinations, Histological effect of venom.

\section{Introduction}

Snakes are wild animals and some species are venomous. Snakes' bites could cause serious health problems by injecting their modified saliva and venoms into another organism for purpose of self-defense and hunting victim. Also, they use these toxic and complex components for paralyzing and digestion preys (WHO, 2010). Most data suggested that snakes cause in more than 3 million bites/year with approximately about 150,000 deaths, particularly in rural tropical areas and at least 421,000 cases of envenoming and 20,000 deaths occur every year worldwide (Gouda et al, 2017). Also, WHO reported that about 5.4 million snake bites occur each year, resulting in 1.8 to 2.7 million cases of envenomings (poisoning from snake bites) and the cases of death between 81,410 and 137, 880 around three times as many amputations and other permanent dis- abilities each year (WHO, 2018).

Echis coloratus (the painted saw-scaled viper) belongs to Viperidae family that comprises Echis carinatus, Echis pyramidum, Cerastes cerastes, Pseudo cerates and Bitis arientans (Al-Asmari et al, 2014). Echis coloratus is found in north-east Africa and throughout Arabia, and spread largely in the mountainous areas (Babocsay, 2004).

The venoms are mixtures of enzymes, peptides, toxins, nerve growth factors, carbohydrates, lipids, metal ions and organic compounds (Chérifi and Laraba-Djebari, 2013). Since the primary role of venom is to aid prey capture, it is perhaps unsurprising that variation in the protein composition of venom has been associated with significant dietary shifts in a number of genera (Sanz et al, 2006). The most numerically abundant venom toxin families in the four Echis species were the SVMPs, CTLs, PLA 2 s, \& SPs that 
broadly consistent with viperid venom gland analyses, although considerable intergeneric variations in the EST-inferred expression levels of these toxin families have been reported (Wagstaff and Harrison, 2006). The enzyme leads to protein causing swelling and necrosis. In addition to phospholipase A2 which affects this enzyme effect on normal physiological processes of the victim that could eventually cause death (Harris and Scott-Davey, 2013). Common names: painted saw-scaled viper, painted carpet viper, Burton's carpet viper (Mallow et al, 2003). A host of other components in $E$. coloratus venom have a specific biological effect on victim but non-lethal including sever pain, swelling, respiratory failure, blood coagulation, disturbance in blood pressure regulation, arrhythmia, muscular impulse, transmission of the nervous, and circulatory collaps which lead to renal failure. The effected liver by E. coloratus venom raise glucose level, glycogen depletion, and raise of alanine aminotransferase (ALT), alkaline phosphatases (ALP), and aspartate aminotransferase (AST) lead to hepatocellular damage (Jarrar, 2011).

Snake poisoning signs and symptoms include numerous clinical abnormalities and development of acute hepato-renal toxicity, organ dystrophy and metabolic complications (Al Asmari et al, 2016). Snake venom poisoning is a medical emergency requiring immediate attention. Bites from poisonous European snakes can lead to local tissue damage and systemic symptoms, which is a potentially serious event that requires immediate hospital care. Yet, the majority of victims can be treated successfully with conservative methods (Frangides et al, 2006).

Gamma radiation has noticeable effect on lowering toxicity from venom without effect on immunogenicity as it can change the molecular structure of proteins (Rogero and Nascimento, 1995). After exposure proteins or in snake's venom, it has to damage of amino acid occur side chains of protein and produce a new group, form intermolecular and intramolecular cross links and splitting of peptide bonds which this change may be in dry or solution state (Rogero and Nascimento, 1995; Al-Sadoon et al, 2013).

\section{Materials and Methods}

Venom: Echis coloratus lyophilized crude venom was obtained from the Egyptian organization of biological products and vaccines (VACSERA).

Detoxification of venom: Gamma radiation of E. coloratus venom was carried out in the National Center for Radiation and Technology (NCRRT, Egypt) using $\mathrm{C}^{60}$ gamma radiation source of Indian facility with a dose rate $0.7 \mathrm{KGy} / \mathrm{hr}$ at the time of the experiment. Samples of dry venom were irradiated to $2,5 \& 10 \mathrm{KGy}$ respectively.

Male albino Swiss mice weighing between $18-20 \mathrm{~g}$ from three to five weeks in age were selected from the experimental animal house of the VACSERA. Animals were kept in standard conditions and fed with normal diet and water.

Lethality assay: Toxicity of E. coloratus venom was carried out on albino Swiss mice (Theakston and Reid, 1983) by intravenous (i.v) injection of different doses of non irradiated venom and irradiated venom $(2,5$ and $10 \mathrm{KGY})$. $\mathrm{LD}_{50}$ was determined by formula: $\mathrm{M}=\mathrm{X}_{\mathrm{k}}+1 / 2 \mathrm{~d}-\mathrm{dr} / \mathrm{N}$

$\mathrm{M}=\log \mathrm{LD}_{50}, \mathrm{X}_{\mathrm{k}}=\log$ dose causing $100 \%$ mortality $\left(\log \mathrm{LD}_{100}\right), \mathrm{d}=$ logarithmic interval of doses, $r=$ Sum of the number of animals dead at each of the individual doses and $\mathrm{N}=$ Number of animals in each group.

Tested animals were divided into three groups as following G1: included 10 mice that served as control. G2: included 10 mice were injected intravenous with a dose of $\mathrm{LD}_{50}$ of native non- irradiated sample (1.245 $\mathrm{mg} / \mathrm{g}$ body weight of mouse).

G3: was subdivided into these groups according to the doses of irradiated venom received: 1- Injection with $2 \mathrm{KGy}$ irradiated venom intravenous with $\mathrm{LD}_{50}$ dose, $(1.245$ $\mathrm{mg} / \mathrm{g}$ body weight of mouse). 2- Injection with $2 \mathrm{KGy}$ irradiated venom intravenous with 5 times $\mathrm{LD}_{50}$ dose, $(6.225 \mathrm{mg} / \mathrm{g}$ body 
weight of mouse). 3- Injection with 5 KGy irradiated venom intravenous with $\mathrm{LD}_{50}$ dose, $(1.245 \mathrm{mg} / \mathrm{g}$ body weight of mouse). 4- Injection with $5 \mathrm{KGy}$ irradiated venom intravenous with 5 times $\mathrm{LD}_{50}$ dose, (6.225 $\mathrm{mg} / \mathrm{g}$ body weight of mouse). 5- Injection with $10 \mathrm{KGy}$ irradiated venom intravenous with $\mathrm{LD}_{50}$ dose, $(1.245 \mathrm{mg} / \mathrm{g}$ body weight of mouse). 6- Injection with $10 \mathrm{KGy}$ irradiated venom intravenous with 5 times $\mathrm{LD}_{50}$ dose, $(6.225 \mathrm{mg} / \mathrm{g}$ body weight of mouse).

Blood was collected from each group of mice 6 hours post-injection from the jugular vein after anesthetizing mice by isoflurane, using disposable syringe to take blood sample according to ethics statement (Hoff and Rlatg, 2000) and collected blood were centrifuged to separate sera at $3000 \mathrm{rpm}$ for 15 min at room temperature and kept at $-70^{\circ} \mathrm{C}$.

Sodium dodecyle sulfate electrophoresis (SDS-PAGE): The 10\% gel was prepared (Laemmli, 1970) to determine the molecular weights of venom in the presence of protein markers. The E. coloratus crude of irradiated venom $(12 \mu \mathrm{g} / \mathrm{ml})$ and non-irrradiated was subjected to preparative $10 \%$ native polyacrylamide gel electrophoresis. The protein samples were mixed with equal volumes of $2 \mathrm{X}$ or $5 \mathrm{X}$ samples buffers and were heated for $10 \mathrm{~min}$ at $100^{\circ} \mathrm{C}$, The comb was slowly removed from the gel to avoid disturbing the well dividers. Each well was filled with tank buffer and the sample was loaded using $50 \mu \mathrm{l}$ or $100 \mu 1$ Hamilton syringe. Electrophoresis was set at 100 to 125 volt. The gel was placed in a container with coomassie stain and shacked for 30 to $60 \mathrm{~min}$ for $1.5 \mathrm{~mm}$ thick gel until bands were visible, as placed with de-stain to clear background.

Biochemical examinations: Blood samples

Table 1: $\mathrm{LD}_{50}$ of mice injected with native $E$. coloratus venom and different doses of irradiated venom at $2,5 \& 10 \mathrm{KGy}$.

\begin{tabular}{|l|c|c|}
\hline Group of mice & Survival & Death \\
\hline LD $_{50}$ of crude venom & 5 & 5 \\
\hline LD $_{50}$ of irradiated venom $(2 \mathrm{KGy})$ & 10 & - \\
\hline 5 times LD & 9 & 1 \\
\hline LD $_{50}$ of irradiated venom $(5 \mathrm{KGy})$ & 10 & - \\
\hline 5 times $\mathrm{LD}_{50}$ of irradiated venom $(5 \mathrm{KGy})$ & 10 & - \\
\hline LD $_{50}$ of irradiated venom $(10 \mathrm{KGy})$ & 10 & - \\
\hline 5 times $\mathrm{LD}_{50}$ of irradiated venom $(10 \mathrm{KGy})$ & 8 & 2 \\
\hline
\end{tabular}

were used for estimation of quantitative Creatinine using commercial kit from Vitro Scient serum urea was determined using kit from Vitro Scient (Rock et al, 1987), activity of serum ALT by Vitro Scient kit (Zilva and Pannall 1979), activity of serum AST by Vitro Scient kit (Henry, 1974) and activity of serum Creatinine phosphokinase using BioScien kit (CK total) after IFCC (1989).

Statistical analysis: All values were expressed as mean \pm standard error and t-test values were calculated using Microsoft Excel 2007 , $\mathrm{P}$ value $<0.01$ was considered significant.

Histological studies: Samples were taken from the liver and kidney of mice in different groups and fixed in 10\% formol saline for twenty four hours. Washing was done in tap water then serial dilutions of alcohol (methyl, ethyl and absolute ethyl) were used for dehydration. Specimens were cleared in xylene and embedded in paraffin at 56 degree in hot air oven for 24hrs. Paraffin bees wax tissue blocks were prepared for sectioning at 4 microns thickness by microtome. Tissue sections were collected on glass slides, deparaffinized, stained by hexatoxylin and eosin stain and examined by light electric microscopy (Bancroft et al, 1996).

\section{Results}

The $\mathrm{LD}_{50}$ of native E. coloratus venom (non- irradiated), irradiated venom 2, $5 \& 10$ KGy was $1.245 \mathrm{mg} / \mathrm{g}$ body weight of mouse. The $\mathrm{LD}_{50}$ of different doses of irradiated venom protected the mice against the venom lethal action. Mice injected with five times of $\mathrm{LD}_{50}$ with irradiated venom $(6.225 \mathrm{mg} / \mathrm{g}$ body weight of mouse) showed survive of mice than native venom (non-irradiated). 
Sodium dodecyle sulfate electrophoresis (SDS-PAGE): E. coloratus crude venom and different doses of irradiated venom at 2 , 5 and 10 KGy were loading to SDSpolyacrylamide gel electrophoresis along with wide molecular weight protein markers (Fig. 1). The molecular weight of protein bands in the crude venom altered than the molecular weight of protein bands in the irradiated venom.

Biochemical examinations showed highly significant increase $(\mathrm{P}<0.001)$ in levels of
ALT, AST, urea and CK in all groups compared to control group. Levels of serum creatinine showed highly significant increase $(\mathrm{P}<0.001)$ in groups treated with $\mathrm{LD}_{50}$ of native venom (non- irradiated), 5 times $\mathrm{LD}_{50}$ of irradiated venom at 2 and $10 \mathrm{KGy}$, But showed significant $(\mathrm{P}<0.05)$ with the groups treated with 5 times $\mathrm{LD}_{50}$ of irradiated venom at $5 \mathrm{KGy}$ and $\mathrm{LD}_{50}$ of irradiated venom at $10 \mathrm{KGy}$ and showed non- significant in the group treated with $\mathrm{LD}_{50}$ of $5 \mathrm{KGy}$ and 2KGy compared to control (Tab. 2).

Table 2: Mean \pm Std. Dev. and P value of mice serum for Creatinine, Urea, ALT, AST \& CK after treating with $\mathrm{LD}_{50}$ of native E. coloratus venom and different doses of irradiated venom at 2, $5 \& 10 \mathrm{KGy}$.

\begin{tabular}{|c|c|c|c|c|c|c|}
\hline Group & Parameter & ALT (U/L) & AST (U/L) & Creatinine $(\mathrm{mg} / \mathrm{dL})$ & Urea (mg/dL) & $\mathrm{CK}(\mathrm{U} / \mathrm{L})$ \\
\hline Control $(\mathrm{N}=10)$ & Mean \pm Std. Dev. & $36.6 \pm 1.14$ & $48 \pm 1.58$ & $0.68 \pm 0.084$ & $36 \pm 1.6$ & $69.8 \pm 0.83$ \\
\hline $\begin{array}{l}\mathrm{LD}_{50} \text { of native venom } \\
(\mathrm{N}=10)\end{array}$ & $\begin{array}{l}\text { Mean } \pm \text { Std. Dev. } \\
P\end{array}$ & $\begin{array}{l}110 \pm 1.58 \\
0.000\end{array}$ & $\begin{array}{l}299 \pm 3.39 \\
0.000\end{array}$ & $\begin{array}{l}1.7 \pm 0.1 \\
0.000 \\
\end{array}$ & $\begin{array}{l}94 \pm 3.16 \\
0.000\end{array}$ & $\begin{array}{l}480.8 \pm 1.92 \\
0.000\end{array}$ \\
\hline $\begin{array}{l}\mathrm{LD}_{50} \text { of } 2 \mathrm{KGy} \\
(\mathrm{N}=10)\end{array}$ & $\begin{array}{l}\text { Mean } \pm \text { Std. Dev. } \\
P\end{array}$ & $\begin{array}{l}74.2 \pm 0.837 \\
0.000\end{array}$ & $\begin{array}{l}183.6 \pm 2.3 \\
0.000\end{array}$ & $\begin{array}{l}0.82 \pm 0.13 \\
0.084\end{array}$ & $\begin{array}{l}44 \pm 1.18 \\
0.000\end{array}$ & $\begin{array}{l}159.2 \pm 1.48 \\
0.000\end{array}$ \\
\hline $\begin{array}{l}5 \mathrm{LD}_{50} \text { of } 2 \mathrm{KGy} \\
(\mathrm{N}=10)\end{array}$ & $\begin{array}{l}\text { Mean } \pm \text { Std. Dev. } \\
P\end{array}$ & $\begin{array}{l}131.2 \pm 1.3 \\
0.000\end{array}$ & $\begin{array}{l}226 \pm 3.16 \\
0.000\end{array}$ & $\begin{array}{l}1.3 \pm 0.0707 \\
0.000\end{array}$ & $\begin{array}{l}79 \pm 3.16 \\
0.000\end{array}$ & $\begin{array}{l}310.2 \pm 0.83 \\
0.000\end{array}$ \\
\hline $\begin{array}{l}\mathrm{LD}_{50} \text { of } 5 \mathrm{KGy} \\
\mathrm{N}=10\end{array}$ & $\begin{array}{l}\text { Mean } \pm \text { Std. Dev. } \\
P\end{array}$ & $\begin{array}{l}48 \pm 0.707 \\
0.000\end{array}$ & $\begin{array}{l}60 \pm 3.16 \\
0.000\end{array}$ & $\begin{array}{l}0.72 \pm 0.0834 \\
0.47\end{array}$ & $\begin{array}{l}47 \pm 1.58 \\
0.000\end{array}$ & $\begin{array}{l}89.4 \pm 1.52 \\
0.000\end{array}$ \\
\hline $\begin{array}{l}5 \mathrm{LD}_{50} \text { of } 5 \mathrm{KGy} \\
(\mathrm{N}=10)\end{array}$ & $\begin{array}{l}\text { Mean } \pm \text { Std. Dev. } \\
P\end{array}$ & $\begin{array}{l}52.4 \pm 1.14 \\
0.000\end{array}$ & $\begin{array}{l}91 \pm 1.58 \\
0.000\end{array}$ & $\begin{array}{l}0.82 \pm 0.0834 \\
0.039\end{array}$ & $\begin{array}{l}55 \pm 1.58 \\
0.000\end{array}$ & $\begin{array}{l}100.4 \pm 1.14 \\
0.000\end{array}$ \\
\hline $\begin{array}{l}\mathrm{LD}_{50} \text { of } 10 \mathrm{KGy} \\
(\mathrm{N}=10)\end{array}$ & $\begin{array}{l}\text { Mean } \pm \text { Std. Dev. } \\
P\end{array}$ & $\begin{array}{l}88 \pm 1 \\
0.000\end{array}$ & $\begin{array}{l}251.8 \pm 1.3 \\
0.000\end{array}$ & $\begin{array}{l}0.82 \pm 0.0834 \\
0.029\end{array}$ & $\begin{array}{l}53 \pm 2.55 \\
0.000\end{array}$ & $\begin{array}{l}210.6 \pm 1.52 \\
0.000\end{array}$ \\
\hline $\begin{array}{l}5 \mathrm{LD}_{50} \text { of } 10 \mathrm{KGy} \\
(\mathrm{N}=10)\end{array}$ & $\begin{array}{l}\text { Mean } \pm \text { Std. Dev. } \\
P\end{array}$ & $\begin{array}{l}96 \pm 1.58 \\
0.000\end{array}$ & $\begin{array}{l}273 \pm 4.69 \\
0.000\end{array}$ & $\begin{array}{l}1.2 \pm 0.0707 \\
0.000\end{array}$ & $\begin{array}{l}74.4 \pm 2.88 \\
0.000\end{array}$ & $\begin{array}{l}369.4 \pm 1.51 \\
0.000\end{array}$ \\
\hline
\end{tabular}

$\mathrm{P} \leq 0.001=$ highly significant, $\mathrm{P} \leq 0.05=$ significant, $\mathrm{P}>0.05$ = non-significant, $\mathrm{P}$ versus control.

\section{Discussion}

No doubt, the snake bites represent a public health concern worldwide (Warrell et al, 2003). Snake venom is a complex mixture composed of different substances, such as toxins, enzymes, growth factors activators and inhibitors with a variety of biological activities that cause multiple metabolic disorders, changing cellular and enzymatic activities in animals as well as releasing many pharmacological substances (Al-Sadoon et al, 2013; Cherifi and Laraba-Djebari, 2013; Tohamy et al, 2014). In this study, the dry venom was irradiated with three different doses of gamma radiation (2, $5 \& 10 \mathrm{KGy})$. The energy absorbed from ionizing radiation can inactivate biological material as direct effect on the molecule itself (Rogero and Nascimento, 1995). Alexander and Hamilton (1960) showed that irradiation of proteins revealed damage to aminoacids side chains, production of new groups, splitting of peptide bonds and formation of intramolecular and intramolecular cross-links. In the present study, detoxification of dry venom showed survives of mice which injected with $\mathrm{LD}_{50}$ and 5 times of $\mathrm{LD}_{50}$ of irradiated venom at 2, $5 \& 10 \mathrm{KGy}$ than crude venom, which agreed with Bennacef-Heffar and Laraba-Djebari (2003) reported that injection of the irradiated venom with two doses of gamma rays ( 1 \& $2 \mathrm{KGy}$ ) were four and nine times less toxic than native venom. On the other hand, Samy et al. (2015) reported that $\mathrm{LD}_{50}$ for native and irradiated $(1.5 \& 3$ KGy) E. coloratus venom was $2.88 \mathrm{mg} / \mathrm{Kg}$, $18.47 \mathrm{mg} / \mathrm{Kg} \& 22.42 \mathrm{mg} / \mathrm{Kg}$ respe- ctively. So, the doses increase in $\mathrm{LD}_{50}$ after irradiation and decrease in toxicity, these finding like the present results, $\mathrm{LD}_{50}$ for native and irradiated venom at $2,5 \& 10 \mathrm{KGy}$ was $1.245 \mathrm{mg} / \mathrm{g}$ and $6.225 \mathrm{mg} / \mathrm{g}$.

The present results showed change in the protein bands after irradiating the crude Echis coloratus at 2, 5 and $10 \mathrm{KGy}$ by subjected to SDS-polyacrylamide gel electro- 
phoresis, agreed with Samiy et al. (2016) reported that the venom components were altered after irradiation, some protein bands gradually disappeared and the intensity of bands decreased. The levels of ALT and AST enzymes are important in evaluating the degree of liver inflammation and hepatic cells necrosis that increase the hepatic cells permeability resulting in the release of these enzymes in blood circulation (Abdel Moniem et al, 2013). The present study showed increase in AST and ALT levels after injection with crude venom. This agreed with Asad et al. (2014) and Riaz et al. (2015) who showed that Naja naja karachiensis venom caused significant increase in ALT and AST levels. Also, our groups injected with different doses of irradiated venom at 2, 5, and $10 \mathrm{KGy}$ showed decrease in the rise of ALT and AST than crude venom, agreed with Hayes and Francis (2001) who reported the resulting in a change in the biological activity of venom after exposure to gamma radiation. Also, Al Asmari, et al. (2016) reported that the administration of Echis coloratus venom to the rats caused significant increase in AST, ALT and ALP and blood serum creatinine levels, when compared with control, which agreed with the present results.

In the current study, the venom was found to induce high significant increase in the concentration of blood urea in both groups treated with dose of venom compared to control group. The group treated with 10 KGy LD $_{50}$ of venom showed more increasing in blood urea level than group treated with $2 \& 5 \mathrm{LD}_{50}$ of venom. Also, the concentration of serum creatinine in both injected groups showed high significant elevation compared to control group. These agreed with El-Missiry et al. (2010) reported that the $\mathrm{LD}_{50}$ of native venom on the kidney and renal functions induced a highly significant increase in urea and creatinine levels compared to the normal control.

The present results revealed that, the mice which injected with different doses of irradi- ated venom $(2,5 \& 10 \mathrm{KG})$ highly significant increase in CK level in compared to control and amount of CK level was less in these groups compared to amount of CK level in group injected with crude venom, agreed with Rogero and Nascimento (1995) who reported that no toxicity no phospholipase activity and no ability to promote CK. Dissanayake et al. (2018) reported that creatinine kinase serves as blood serum indicator of tissue destructions associated with skeletal and cardiac muscles and possible renal dysfunction and inflated levels of CK in blood serum of all envenomed mice regardless to toxic involvement of venom. Hemmaid (2010) found severe histopathological changes after $4 \mathrm{hr}$ of Naja haje crude venom injection. The present study showed histopathological alternation after $6 \mathrm{hr}$.

In the present study, inflammatory cells infiltration was observed in the portal area as well as in between the hepatocytes associated with diffuse kupffer cells proliferation in the groups injected with $\mathrm{LD}_{50}$ of native venom and 5 times $\mathrm{LD}_{50}$ of irradiated groups (2, $10 \mathrm{KGy})$. These findings agreed with studies revealed that Naja haje envenoming causes cellular swelling, cytoplasmic granulation and vacuolization in addition to intra hepatic hemorrhage, liver necrosis and activation and hyperplasia of the Kupffer cells (Rahmy and Hemmaid, 2000; Nanayakkara et al, 2009; Ghani et al, 2010; Tohamy et al, 2014; Abdou and Ibrahimm 2015).

On the other hand, there was no change in liver and kidney in groups injected with $\mathrm{LD}_{50}$ irradiated venom at 2, 5, $10 \mathrm{KGy}$ and 5 times of $\mathrm{LD}_{50}$ at $5 \mathrm{KGy}$ agreed with Abib and Laraba-Djebari (2003) reported that the native venom caused severe degenerative changes in the myocardium but, in case of 2 KGy irradiated venom, no tissue alterations were observed.

The current study showed marked histological changes in renal tissue in the form of focal necrosis of the tubules and glomeruli (infarction) associated with perivascular inflammatory cells infiltration surrounding the 
cortical blood vessels as well as degeneration in the tubular lining epithelium agreed with Al-Johany et al. (2015) who reported that renal failure can be expected after envenomation by $E$. pyramidum venom with a serious course of intoxication.

\section{Conclusion}

The results showed the detoxification of dry Echis coloratus venom with 2, 5 \& $10 \mathrm{KGy}$ of gamma radiation reduced venom toxicity with an optimum safety $5 \mathrm{KGy}$ dose.

\section{Acknowledgment}

The authors are grateful to Prof. Dr. Ayman Diab, Dean, Faculty of Biotechnology, and Prof. Dr. Gehan Safwat, Vice Dean, for supporting and facilitating this work. Thanks are also due to VACSERA authorities.

\section{References}

Abdel Moneim, AE, Othman, MS, Mohmoud, SM, El-Deib, KM, 2013: Pomegranate peel attenuates aluminum-induced hepatorenal toxicity. Toxicol. Mech. Meth. 23, 8:624-33.

Abdou, RH, Ibrahim, AE, 2015: Effects of Egyptian cobra (Naja haje) venom on post mortem changes and some biochemical parameters in rats. Inter. J. Sci. Res., 4, 1:186-90.

Abib, H, Laraba-Djebari, F, 2003: Effects of 60 Co gamma radiation on toxicity and hemorrhagic, myonecrotic, and edema-forming activities of Cerastes cerastes venom. Canad. J. Physiol. Pharmacol. 81:1125-30.

Al-Asmari, A, Khan AA, Manthiri, RA, 2014: Chemical fingerprinting of Saudi Arabian snake venoms using gel filtration chromatography. Biomed. Res. 25:138-40

Alexander, P, Hamilton, LDG, 1960: Irradiation of proteins in the solid state. II. Chemical changes produced in bovine serum albumin. Radiat. Res. 13:214-33.

Al-Johany, AM, Al-Sadoon, MK, Abdel Moneim, AE, Bauomy, AA, Diab, MSM, 2015: Histological, molecular and biochemical detection of renal injury after Echis pyramidum snake envenomation in rats. Saudi J. Biol. Sci. 22:30211.

Al-Sadoon, MK, Abdel Moneim, AE, Diab, M M, Bauomy, AA, 201): Hepatic and renal tissue damages induced by Cerastes cerastes gasperet$t i$ crude venom. Life Sci. J. 10, 4:191-7.

Asad, MHHB, Murtaza, G, Ubaid, M, Sajjad, A, Mehmood, R, et al, 2014: Naja naja kara- chiensis envenomation: biochemical parameters for cardiac, liver, and renal damage along with their neutralization by medicinal plants. Biomed/ Res. Inter. Vol. pages

Babocsay, G, 2004: A new species of saw-scaled viper of the Echis coloratus complex (Ophidia: Viperidae) from Oman, Eastern Arabia. Systemat. Biodiver. 1, 4:503-14.

Bancroft, GD, Stevens, A, Turner, DR, 1996: Theory and Practice of Histological Techniques. Churchill: Livingston. New York.

Beneficial role of quercetin on Echis coloratus snake venom induced hepato-renal toxicity in rats. J. Biol. Sci. 16:112-9.

Bennacef-Heffar, N, Laraba-Djebari, F, 2003: Evaluation of the effect of gamma rays on the venom of Vipera lebetina by biochemical study. cal Chemistry) Scientific Division, Committee on $\mathrm{pH}$, Blood Gases and Electrolytes: Guidelines for Transcutaneouspo2 and pco2 Measurement. J. Autom. Chemis. 11:235-9.

Can. J. Physiol. Pharmacol. 81:1110-7.

Chérifi, F, Laraba-Djebari, F, 2013: Isolated biomolecules of pharmacological interest in hemostasis from Cerastescerastes venom. J. Venom. Anim. Toxins Trop. Dis. 19, 1:11-8.

Dissanayake, DSB, Thewarage, LD, Waduge, RN, Ranasinghe, JGS, Kularatne, SAM, et al, 2018: The venom of spectacled cobra (Elapidae: Naja naja): In vitro study from distinct geographical origins in Sri Lanka. J. Toxicol. V. 2018, Article ID 7358472, https://doi.org/10.1155/ 2018/ 7358472

El-Missiry, AG, Shaban, EA, Mohamed, MR, Ahmed, AA, Abdallah, NM, et al, 2010: Influence of ionizing radiation on Echis pyramidum snake venom: biochemical and immunological aspects. Egypt. J. Hosp. Med. 40:314-34.

Frangides, CY, Koulouras, V, Kouni, SN Tzortzatos, GV, Nikolaou, A, et al, 2006: Snake venom poisoning in Greece: Experiences with 147 cases. Eur. J. Intern. Med. 17, 1:24-7.

Ghani, LMA, El-Asmer, MF, Abbas, OA, Rahmy, TR, 2010: Histological and immunohistochemical studies on the nephrotoxic effects of Naja nigricollis snake venom. Egyptian J. Nat. Toxins 7:1/2:29-52.

Gouda, AS, Elnabarawy, NA, Badawy, SM, 2017: A study of snakebite envenomation cases admitted to Egyptian national poisoning center. Acta Med. Int. 4:34-40.

Harris, JB, Scott-Davey, T, 2013: Secreted phospholipases A2 of snake venoms: effects on the 
peripheral neuromuscular system with comments on the role of phospholipases A2 in disorders of the CNS and their uses in industry. Toxins 17:2533-71.

Hayes, AW, Francis, T, 2001: Principle and Methods of Toxicological. $4^{\text {th }}$ edition by Wallace Hayes, Taylor and Francis.

Hemmaid, K.Z, 2010: Histological and ulrastructure alterations in the renal cortex of rats induced by the Egyptian cobra (Naja haje) crude venom. Egypt. J. Exp. Biol. (Zool.), 6, 2:319-30. Henry, JB, 1974: Clinical Diagnosis and Management by Laboratory Methods. W.B. Saunders \& Co., Philadelphia, PA.

Hoff, J, Rlatg, LVT, 2000: Methods of blood collection in the mouse. Lab. Anim. 29, 10:4753 .

Jarrar, BM, 2011: Histological alterations and biochemical changes in the liver of sheep following Echis coloratus envenomation. Saudi J. Biol. Sci. 18, 2:169-74.

Laemmli, U, 1970: Cleavage of structural proteins during the assembly of the head of bacteriophage T4. Nature 227:680-5.

Mallow, D, Ludwig, D, Nilson, G. 2003: True Vipers: Natural History and Toxinology of Old World Vipers. Malabar, Florida: Krieger Publishing Company

Nanayakkara, DP, Ratnayake, RMP, Ranasinghe, JG, 2009: Histopathological changes in brain, kidney and liver of mice following intramuscular administration of krait venom. Ceylon J. Sci. (Biol. Sci.), 38, 1:1-10.

Rahmy, TR, Hemmaid, K.Z, 2000: Histological and histochemical alterations in the liver following intramuscular injection with a sublethal dose of the Egyptian cobra venom. J. Nat. Toxins $9,1: 21-32$.

Riaz, Z, Zaman, MQ, Ullah, HUR, Yousaf, M S, Rabbani, I, et al, 2015: Bio-physiological effects of $\mathrm{LD}_{50}$ of crude venom of Black Pakistani Cobra (Naja Naja karachiensis) in mice. JAPS, J. Anim. Plant Sci. 25, 5:1344-8.

Rock, RC, Walker, WG, Jennings, CD, 1987:
Nitrogen metabolites and renal function. In: Tietz N W, ed. Fundamentals of Clinical Chemistry. $3^{\text {rd }}$ ed. Philadelphia: WB Saunders.

Rogero, JR, Nascimento, N, 1995: Detoxification of snake venom using ionizing radiation. J. Venom. Anim. Toxin. vol. $1 \mathrm{n}$. 1 Botucatu http: //dx.doi.org/10.1590/S0104-7930199500010002.

Samy, EM, Shaaban, ES, Kenawy, SA, Galal, MA, Salama, WH, 2015: Evaluation of the effect of gamma rays on Echis coloratus snake venom through toxicological, immunological and biological studies. Inter. J. Sci. Res. Publication, 5: ISSN 2250-3153.

Sanz, L, Gibbs, HL, Mackessy, SP, Calvete, J J, 2006: Venom proteomes of closely related $\mathrm{Si}$ strurus rattlesnakes with divergent diets. J/ Proteome Res. 5:2098-112.

Theakston, RDG, Reid, HA, 1983: Development of simple standard assay procedures for the characterization of snake venom. Bull. WHO 61:949-56

Tohamy, AA, Mohamed, AF, Moneim, AEA, Diab, MS, 2014: Biological effects of Naja haje crude venom on the hepatic and renal tissues of mice. J. King Saud Univ. Sci. 26, 3:205-12.

Wagstaff, SC, Harrison, RA, 2006: Venom gland EST analysis of the saw-scaled viper, Echis ocellatus, reveals novel $\alpha_{9} \beta_{1}$ integrin-binding motifs in venom metalloproteinases and a new group of putative toxins, renin-like aspartic proteases. Gene 377:21-32.

WHO, 2010: Venomous snakes' distribution and species risk categories. Available at: http://apps. who.int/bloodproduct/snakeantivenoms/database WHO, 2018: Snakebite envenoming, Global, 20 February.

Warrell, DA, Gutiérrez, JM, Calvete, JJ, Williams, D, 2013: New approaches \& technologies of venomics to meet the challenge of human envenoming by snakebites in India. Indian $\mathrm{J}$. Med. Res. 138, 1:38-59

Zilva, JF, Pannall, PR, 1979: Plasma Enzymes in Diagnosis in Clinical Chemistry in Diagnosis and Treatment. Lioyd-Luke London.

\section{Explanation of figures}

Fig. 1: SDS-PAGE of Echis coloratus venom. Lane 1 molecular weights of standard proteins, lane 2native non-irradiated venom, lane 3 irradiated venom at $2 \mathrm{KGy}$, lane 4 irradiated venom at $5 \mathrm{KGy}$ and lane 5irradiated venom at $10 \mathrm{KGy}$.

Fig. 2: Liver sections of mice a- control shows central vein surrounded by normal hepatocytes b- $\mathrm{LD}_{50}$ of native venom shows inflammatory cells infiltration in portal area and between hepatocytes with diffuse kupffer cells proliferation c- $\mathrm{LD}_{50} 2 \mathrm{KGy}$ shows no histological alterations d- $5 \mathrm{LD}_{50} 2 \mathrm{KGy}$ showing inflammatory cells infiltration with congestion in portal vein and degeneration in hepatocytes e\&f- LD ${ }_{50}, 5$ $\mathrm{LD}_{50} 5 \mathrm{KG} \& \mathrm{~g}-\mathrm{LD}_{50} 10 \mathrm{KGy}$ shows normal h- $5 \mathrm{LD}_{50} 10 \mathrm{KGy}$ shows massive inflammatory cells aggregation in portal area (H\&E $\left.\mathrm{x} 40\right)$.

Fig. 3: Kidney sections of mice (A) control showing normal structure of glomeruli and tubules at cortex (B) LD Do $_{50}$ of native venom showing focal inflammatory cells aggregation in between degenerated renal tubules at cortex (C) ) $\mathrm{LD}_{50} 2 \mathrm{KGy}$ showing no histological alterations (D) $5 \mathrm{LD}_{50} 2 \mathrm{KGy}$ showing degenerative change in lining epithelium of tubules at cortex (E) $\mathrm{LD}_{50} 5 \mathrm{KGy}$ showing no histological alterations (F) 5 $\mathrm{LD}_{50} 5 \mathrm{KGy}$ showing congestion in cortical blood vessels $(\mathrm{G}) \mathrm{LD}_{50} 10 \mathrm{KG}$ showing normal renal structure $(\mathrm{H}) 5 \mathrm{LD} 5010 \mathrm{KGy}$ showing focal necrosis of tubules and glomeruli (infiltration) at cortical portion. 

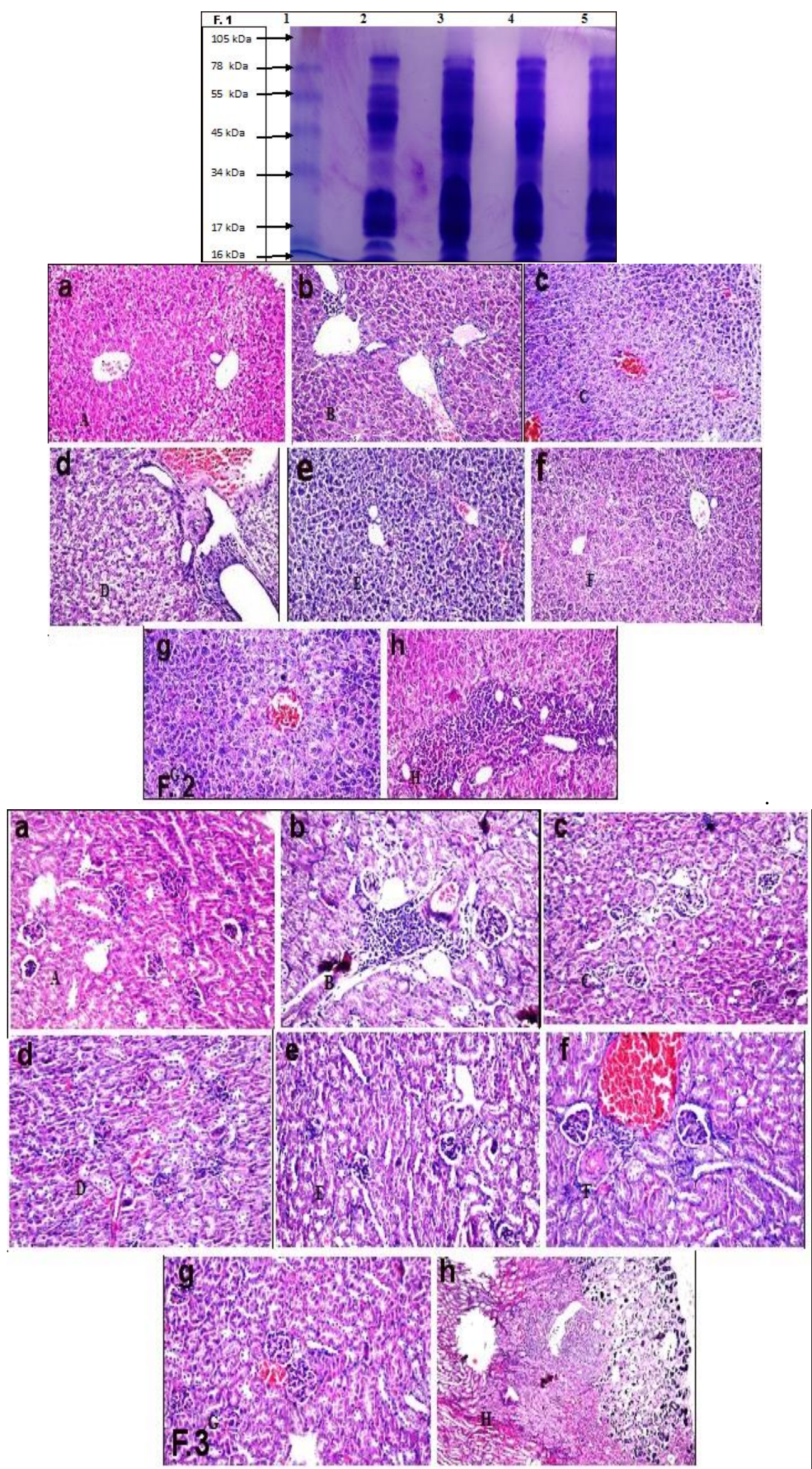